\title{
Trends in atmospheric ammonia at urban, rural, and remote sites across North America
}

\author{
Xiaohong Yao ${ }^{1}$ and Leiming Zhang ${ }^{2}$ \\ ${ }^{1}$ Lab of Marine Environmental Science and Ecology, Ministry of Education, Ocean University of China, \\ Qingdao 266100, China \\ ${ }^{2}$ Air Quality Research Division, Science and Technology Branch, Environment and Climate Change Canada, \\ 4905 Dufferin Street, Toronto, Ontario, M3H 5T4, Canada
}

Correspondence to: Xiaohong Yao (xhyao@ouc.edu.cn) and Leiming Zhang (leiming.zhang@canada.ca)

Received: 26 March 2016 - Published in Atmos. Chem. Phys. Discuss.: 23 May 2016

Revised: 28 August 2016 - Accepted: 31 August 2016 - Published: 14 September 2016

\begin{abstract}
Interannual variabilities in atmospheric ammonia $\left(\mathrm{NH}_{3}\right)$ during the most recent $7-11$ years were investigated at 14 sites across North America using the monitored data obtained from NAPS, CAPMoN and AMoN networks. The long-term average of atmospheric $\mathrm{NH}_{3}$ ranged from 0.8 to $2.6 \mathrm{ppb}$, depending on location, at four urban and two rural/agricultural sites in Canada. The annual average at these sites did not show any deceasing trend with largely decreasing anthropogenic $\mathrm{NH}_{3}$ emission. An increasing trend was actually identified from 2003 to 2014 at the downtown Toronto site using either the Mann-Kendall or the ensemble empirical mode decomposition method, but "no" or "stable" trends were identified at other sites. The $\sim 20 \%$ increase during the 11-year period at the site was likely caused by changes in $\mathrm{NH}_{4}^{+}-\mathrm{NH}_{3}$ partitioning and/or air-surface exchange process as a result of the decreased sulfur emission and increased ambient temperature. The long-term average from 2008 to 2015 was $1.6-4.9 \mathrm{ppb}$ and $0.3-0.5 \mathrm{ppb}$ at four rural/agricultural and at four remote US sites, respectively. A stable trend in $\mathrm{NH}_{3}$ mixing ratio was identified at one ru$\mathrm{ral} /$ agricultural site while increasing trends were identified at three rural/agricultural $(0.6-2.6 \mathrm{ppb}, 20-50 \%$ increase from 2008 to 2015$)$ and four remote sites (0.3-0.5 ppb, 100-200\% increase from 2008 to 2015). Increased ambient temperature was identified to be a cause for the increasing trends in $\mathrm{NH}_{3}$ mixing ratio at four out of the seven US sites, but what caused the increasing trends at other US sites needs further investigation.
\end{abstract}

\section{Introduction}

Atmospheric ammonia $\left(\mathrm{NH}_{3}\right)$ plays an important role in formation of ammonium sulfate and nitrate aerosols in the size range of nanometer to supermicron (Yao et al., 2007; Kulmala et al., 2004; Ianniello et al., 2011; Yao and Zhang, 2012; Schiferl et al., 2014; Paulot and Jacob, 2014). The sum of sulfate, nitrate, and ammonium ions $\left(\mathrm{NH}_{4}^{+}\right)$usually consists of the major portion of $\mathrm{PM}_{2.5}$ across Canada and the United States (Dabek-Zlotorzynska et al., 2011; Hand et al., 2012). With significant decreases in acidic gas emissions in the last decades across North America (e.g., emissions of $\mathrm{SO}_{2}$ and $\mathrm{NO}_{x}$ in Canada decreased from $2.28 \times 10^{6}$ and $2.72 \times 10^{6}$ t year $^{-1}$ in 2003 to $1.23 \times 10^{6}$ and $2.06 \times 10^{6} \mathrm{t} \mathrm{year}^{-1}$ in 2013 , respectively (http://www.ec.gc. ca/inrp-npri/donnees-data/ap/index.cfm?lang=En)), more attention is being paid to the relationship between $\mathrm{NH}_{3}$ and $\mathrm{NH}_{4}^{+}$aerosols (Zhang et al., 2010; Day et al., 2012; Nowak et al., 2012; Yao and Zhang, 2012; Schiferl et al., 2014; Zhu et al., 2013; Markovic et al., 2014; Paulot and Jacob, 2014).

$\mathrm{NH}_{3}$ mixing ratios are affected by several factors such as $\mathrm{NH}_{3}$ emissions, $\mathrm{NH}_{3}-\mathrm{NH}_{4}^{+}$partitioning, and meteorological conditions (Sutton et al., 2009; Yao and Zhang, 2013; $\mathrm{Hu}$ et al., 2014). In Europe, previous studies showed that the long-term trend in atmospheric $\mathrm{NH}_{3}$ observed in some countries did not reflect the dramatic decrease in $\mathrm{NH}_{3}$ emissions and the phenomenon was referred to as "ammonia gap" (Sutton et al., 2009; Ferm and Hellsten, 2012; Sintermann et al., 2012). Long-term trends in atmospheric $\mathrm{NH}_{3}$ across North America are poorly understood (Zbieranowski and Aherne, 2011; Hu et al., 2014; Van Damme et al., 2014). 
Such knowledge is important for accurate prediction of ammonium sulfate and nitrate aerosol levels in the future (Pye et al., 2009; Walker et al., 2012). In North America, established anthropogenic $\mathrm{NH}_{3}$ emission inventories showed that agricultural emissions accounted for over $80 \%$ of the total anthropogenic $\mathrm{NH}_{3}$ emissions (Lillyman et al., 2009; Behera et al., 2013; Xing et al., 2013). However, agricultural emission sources only affect mixing ratios of atmospheric $\mathrm{NH}_{3}$ at short downwind distances (Theobald et al., 2012; Yao and Zhang, 2013). Non-agricultural emissions such as those from local traffic, waste containers, and soil and vegetation were reported to be important contributors to $\mathrm{NH}_{3}$ in urban atmospheres (Whitehead et al., 2007; Ellis et al., 2011; Reche et al., 2012; Sutton et al., 2013; Yao et al., 2013; $\mathrm{Hu}$ et al., 2014), although these sources only accounted for a few percentage of the total $\mathrm{NH}_{3}$ emissions in Canada and the United States. Due to new technology adopted, traffic-derived $\mathrm{NH}_{3}$ decreased gradually (Bishop et al., 2010; http://www.ec.gc.ca/inrp-npri/donnees-data/ap/ index.cfm?lang=En). Yao et al. (2013) and $\mathrm{Hu}$ et al. (2014) recently reported that traffic-derived $\mathrm{NH}_{3}$ was a negligible contributor to atmospheric $\mathrm{NH}_{3}$ in Toronto. However, under climate warming, soil and vegetation $\mathrm{NH}_{3}$ emissions are expected to increase accordingly. For example, $\mathrm{NH}_{3}$ volatilization potential nearly doubles under every $5^{\circ} \mathrm{C}$ increase (Pinder et al., 2012; Sutton et al., 2013; Fowler et al., 2015).

Atmospheric $\mathrm{NH}_{3}$ and ammonium sulfate and nitrate aerosols can be transported downwind and eventually deposited to natural ecosystems to enhance carbon fixation (Krupa, 2003; Beem et al., 2010; Walker et al., 2012). Excessive $\mathrm{NH}_{3}$ deposition may cause adverse effects such as reduced biodiversity and eutrophication (Krupa, 2003; Erisman et al., 2007; Beem et al., 2010; Bobbink et al., 2010; Pinder et al., 2012). Recent evidence shows changes in species composition for sensitive vegetation types at the annual average concentration of $1 \mu \mathrm{g} \mathrm{m}^{-3} \mathrm{NH}_{3}$ (Cape et al., 2009). Climate warming may increase the vulnerability of ecosystems towards exposure to $\mathrm{NH}_{3}$ (Pinder et al., 2012). Thus, trend analysis of atmospheric $\mathrm{NH}_{3}$ at remote sites will help to better understand its potential impacts on sensitive natural ecosystems.

In this paper, interannual variabilities in atmospheric $\mathrm{NH}_{3}$ at 14 sites across Canada and the United States were investigated, with particular attention paid to its long-term trends and causes. The 14 sites include 4 urban sites, 4 remote sites and 6 rural/agricultural sites distributed at different latitudes. Two trend analysis tools, i.e., the Mann-Kendall (M-K) analysis (Gilbert, 1987) and the ensemble empirical mode decomposition (EEMD, Wu and Huang, 2009), were used to resolve the time series of atmospheric $\mathrm{NH}_{3}$ in mixing ratio at these sites. The analysis results provided new light on the long-term trends in atmospheric $\mathrm{NH}_{3}$ at various sites across North America.

\section{Methodology}

\subsection{Data sources of atmospheric $\mathrm{NH}_{3}$}

In this study, mixing ratios of atmospheric $\mathrm{NH}_{3}$ generated at monthly interval were compiled from three data sources, i.e., the Canadian National Air Pollution Surveillance (NAPS, http://www.ec.gc.ca/rnspa-naps/) network, the Canadian Air and Precipitation Monitoring Network (CAPMoN; http://www.ec.gc.ca/natchem/default.asp?lang= En\&n=90EDB4BC-1), and the US Passive Ammonia Monitoring Network (AMoN, http://nadp.sws.uiuc.edu/AMoN). Missing data are a common problem during long-term observations. The sites chosen in this study were based on data availabilities as detailed below.

The NAPS network provides accurate and long-term air quality data across Canada. At each site, a Partisol Model 2300 sequential speciation sampler (Thermo Scientific) equipped with dry denuders is used to measure concentrations of $\mathrm{NH}_{3}$ and acidic gases and particulate chemical components such as $\mathrm{pNH}_{4}^{+}$and $\mathrm{pNO}_{3}^{-}$in $\mathrm{PM}_{2.5}$. The sampler maintains a constant flow rate of $10 \mathrm{~L} \mathrm{~min}^{-1}$ and operates for a $24 \mathrm{~h}$ duration on every third day. The $24 \mathrm{~h}$ integrated denuder and filter samples were carried back to the lab where they were extracted and analyzed by ion chromatography (Dabek-Zlotorzynska et al., 2011). At a few sites, technical problems resulted in $\mathrm{NH}_{3}$ and $\mathrm{pNH}_{4}^{+}$concentration data missing for several months. At four urban sampling sites and one rural/agricultural site (Fig. 1), the measurements allowed obtaining continuous time series of monthly averaged concentrations of atmospheric $\mathrm{NH}_{3}$ and $\mathrm{pNH}_{4}^{+}$and were thereby used for trend analysis. However, these sites also suffer from the problem of missing data. For example, there were only $70-90 \%$ months when $8-10$ sets of $24 \mathrm{~h}$ data were available to calculate the monthly average value (Fig. S1 in the Supplement). This may cause uncertainty on the calculated trends in atmospheric $\mathrm{NH}_{3}$ and $\mathrm{pNH}_{4}^{+}$. Moreover, one site at $\mathrm{Eg}$ bert in the southern Ontario (Fig. 1), the part of CAPMoN, also had the long-term measurement concentrations of atmospheric $\mathrm{NH}_{3}$ and $\mathrm{pNH}_{4}^{+}$using the identical sampler as used in the NAPS network. The site is located in a rural/agricultural area. The data were also averaged monthly for the trend analysis. The six Canadian sites were referred to as Sites 1-6 on the basis of their annual average mixing ratios of atmospheric $\mathrm{NH}_{3}$ in decreasing order.

The AMoN within the National Atmospheric Deposition Program in the United States started operation in fall 2007. An important objective of $\mathrm{AMoN}$ is to assess long-term trends in $\mathrm{NH}_{3}$ concentrations and its deposition. AMoN included only 16 sites in 2007, and dozens of sites are now available. The Radiello ${ }^{\circledR}$ passive samplers are deployed every 2 weeks at each site according to the standard operating procedure for monitoring atmospheric $\mathrm{NH}_{3}$. Puchalski et al. (2015) recently compared the bi-weekly passive measurements with those measured by annular denuder systems 


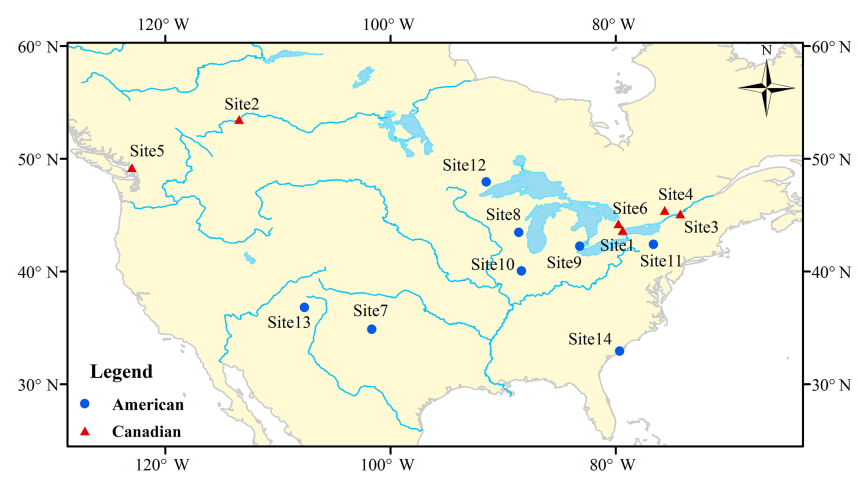

Figure 1. Map of 14 long-term atmospheric $\mathrm{NH}_{3}$ monitoring sites across North America (NAPS Sites 1-5, CAPMoN Site 6 and AMoN Sites 7-14).

(ADSs) at several AMoN sites and found that the mean relative percentage difference between the ADS and AMoN sampler was $-9 \%$. In this study, mixing ratios of atmospheric $\mathrm{NH}_{3}$ at eight $\mathrm{AMoN}$ sites were selected for the trend analysis on the basis of two criteria (Fig. 1): (1) the length of the valid data should be at least 7 years according to Walker et al. (2000), and (2) there were no monthly average data missing each year. The eight sites were referred to as Sites 7-14 (Fig. 1), four of which were located in rural areas and another four in remote areas. Consistent with the six sites across Canada, the monthly averages at the eight sites were used for data analysis if not specified. Moreover, all ambient temperature $(T)$ data were obtained from on-site records or nearby meteorological stations.

\subsection{Statistical methods}

The $\mathrm{M}-\mathrm{K}$ analysis is a non-parametric statistical procedure which can be used to analyze trends in data sets including irregular sampling intervals, data below the detection limit, and trace or missing data (Kampata et al., 2008). Considering that the data flaws aforementioned were indeed present in our selected data sets to a certain extent, the M-K analysis is thereby used to resolve the time series of the annual average of $\mathrm{NH}_{3}$ in this study. According to the analysis, the time series of $n$ data points and $T_{i}$ and $T_{j}$ as two subsets of data where $i=1,2,3, \ldots n-1$ and $j=i+1, i+2, i+3, \ldots$ $n$ are considered. The series of data is used to calculate $S^{\prime \prime}$ statistic, confidence factor and coefficient of variation. The calculated values were further used to test the null hypothesis $\mathrm{H}_{0}$ assuming that there is no trend and the alternative hypothesis $\mathrm{H}_{1}$ assuming that there is a trend, yielding qualitative trend results such as "increasing/decreasing", "probable increasing/decreasing", "stable", and "no trend" (Gilbert, 1987). Moreover, the EEMD is a recently developed statistical tool to determine the trend of a time series of a variable in various fields such as economics, health, environment, and climate (Wu and Huang, 2009). The EEMD built on Empir- ical Mode Decomposition (EMD) and was updated by Wu and Huang (2009) to overcome the problem of mode mixing in the EMD. The method has since been applied widely (e.g., Erturk et al., 2013; Ren et al., 2014) because it is most suitable for resolving non-stationary and non-linear signals. The mixing ratio of atmospheric $\mathrm{NH}_{3}$ was affected not only by its emissions, atmospheric transport, dilution, and deposition but also by non-stationary and non-linear chemical reactions (Ianniello et al., 2011; Hu et al., 2014). Thus, the EEMD is also used in this study and is briefly introduced here.

In general, all data are amalgamations of signal and noise as shown below:

$X(t)=S(t)+N(t)$

where $X(t)$ is the record data, and $S(t)$ and $N(t)$ are the true signal and noise, respectively. In the EMD, any data set is assumed to consist of different simple intrinsic modes of oscillations. Each of these intrinsic oscillatory modes is represented by an intrinsic mode function (IMF). In the EEMD, white noise is added to the single data set, $X(t)$, and the ensemble mean is used to improve accuracy of measurements.

\section{Results and discussion}

\subsection{Temporal variations of atmospheric $\mathrm{NH}_{3}$ at the six Canadian sites}

Figure 2 shows monthly variations of atmospheric $\mathrm{NH}_{3}$ in mixing ratio at the six Canadian sites. At Site 1, an urban site in downtown Toronto, the measured mixing ratios were $2.6 \pm 1.2 \mathrm{ppb}$ (average \pm standard deviation) during the period from July 2003 to June 2014 (Fig. 2a and Table 1). When compared with those reported in other urban atmospheres, the long-term average value of $2.6 \mathrm{ppb}$ ranked at a moderately low concentration level (Whitehead et al., 2007; Saylor et al., 2010; Alebic-Juretic, 2008; Meng et al., 2011). Interannual variations were evident at Site 1 with the coefficient of variation $(\mathrm{CV})$ of 0.11 , defined as the ratio of the standard deviation to the average. It should be noted that the annual averages in 2004 and 2005 were calculated from July 2003 to June 2004 and from July 2004 to June 2005, respectively, instead of a calendar year, in order to obtain the longest time series of annual averages. The similar calculations were used for other years and other sites. The M-K analysis result suggested an increasing trend from 2004 to 2014 with a confidence level of $98 \%$. When intra-annual variations were analyzed at Site 1, a distinctive seasonal trend was obtained with the highest seasonal average value of $3.7 \pm 0.7 \mathrm{ppb}$ in summer (June to August) and the lowest of $1.3 \pm 0.6$ in winter (December to the next February).

The M-K analysis results showed either "no" or "stable" trends in atmospheric $\mathrm{NH}_{3}$ at the other Canadian sites with long-term average of $2.4 \pm 0.6 \mathrm{ppb}$ at Site 2, $2.1 \pm 1.2 \mathrm{ppb}$ at Site 3, $1.9 \pm 0.8 \mathrm{ppb}$ at Site 4, 1.6 $\pm 0.5 \mathrm{ppb}$ at Site 5, and 

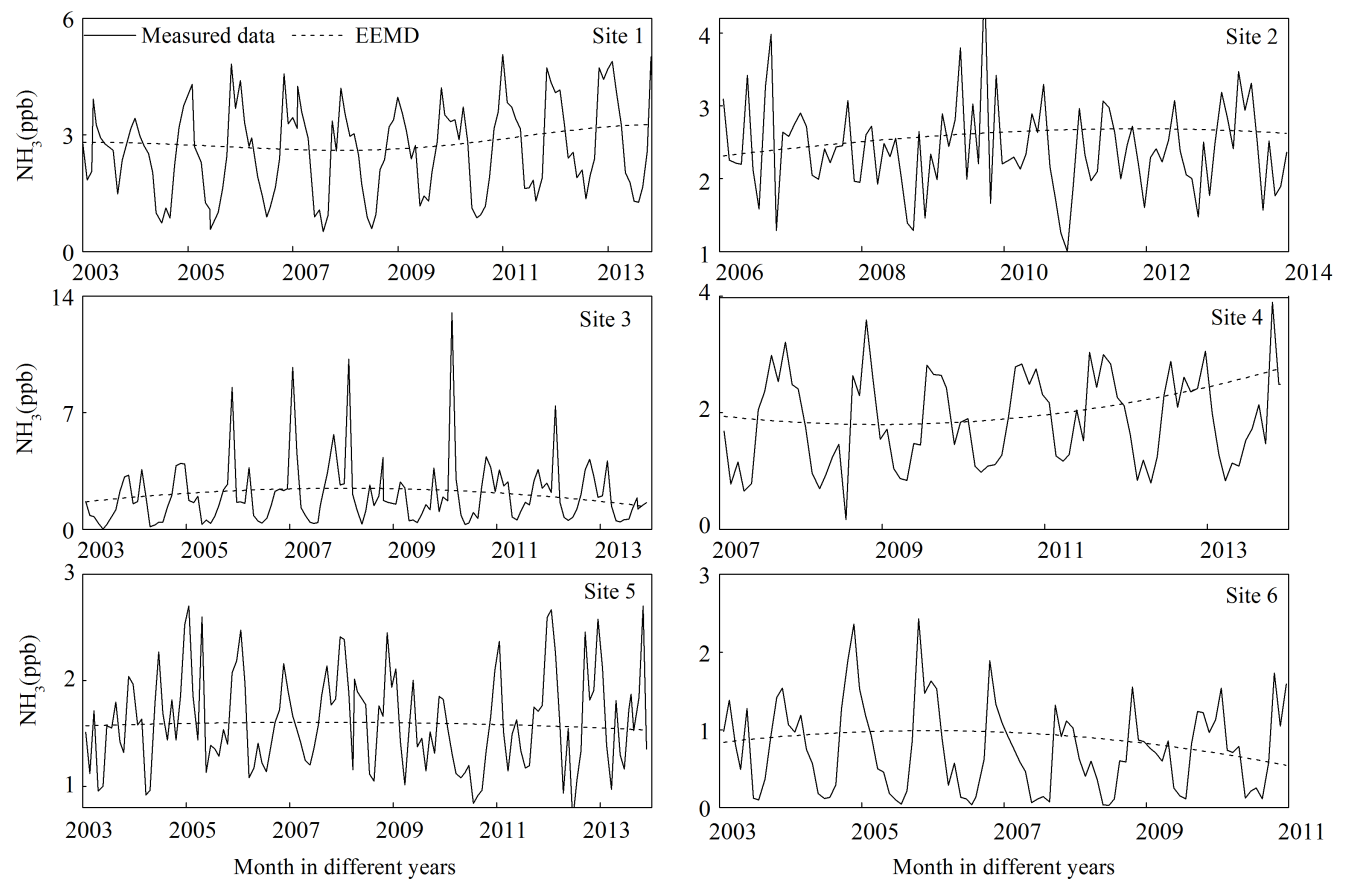

Figure 2. Monthly averages of measured atmospheric $\mathrm{NH}_{3}$ and its long-term trends extracted using the EEMD at six Canadian sites.

$0.8 \pm 0.6 \mathrm{ppb}$ at Site 6 (Fig. 2b-f). However, interannual variations at these sites were evident. For example, the $\mathrm{CV}$ values calculated from annul averages varied from 0.07 to 0.19 , depending on location (Table 1). Atmospheric $\mathrm{NH}_{3}$ at Sites 3, 4 , and 6 exhibited a distinctive seasonal variation, but this was not the case at Sites 2 and 5. The largest seasonal variation occurred at Site 3 while the smallest occurred at Site 2. The two sites were selected as examples for further discussion below.

Site 3 is situated in a rural/agricultural area in Saint-Anicet of Québec. The largest seasonal average value occurred in the fall during the measurement period of September 2003August 2014. Fertilizer application in the late fall (mid- to late October) is very common in Canada (Lillyman et al., 2009). Fertilizer is applied at the time when the turf has stopped growing but is still green. Such a practice can ensure early growing in the following spring. With the late-fall fertilizer application, spring fertilization can be postponed until late May to early June. The fertilizer application usually leads to a sharp increase in atmospheric $\mathrm{NH}_{3}$ mixing ratio (Lillyman et al., 2009; Yao and Zhang, 2013), and this was indeed observed at Site 3. For example, there was usually one $24 \mathrm{~h}$ sample in October having a mixing ratio 1-2 orders of magnitude higher than other samples collected before or after. The on-site sampling was performed every third day, and strong $\mathrm{NH}_{3}$ emissions associated with fertilization application generally occurred within the initial $3-5$ days (Lillyman et al., 2009). Thus, extremely high mixing ratios could be observed on one day in October some years but not every year.
The episodes further led to large interannual variations with the value of CV reached 0.19 .

Site 2 is located in an urban area in Edmonton. Mixing ratios of atmospheric $\mathrm{NH}_{3}$ were $2.4 \pm 0.6 \mathrm{ppb}$, and the differences between seasonal average values were only $0.1-$ $0.3 \mathrm{ppb}$ during the period of May 2006-April 2014. However, the seasonal average temperature of $16.7 \pm 1.9^{\circ} \mathrm{C}$ in summer was much higher than that of $-19.8 \pm 4.5^{\circ} \mathrm{C}$ in winter. The small seasonal variations in $\mathrm{NH}_{3}$ mixing ratio at this site were caused by two contrasting factors in winter season. On the one hand, extremely low temperature limited soil and vegetation $\mathrm{NH}_{3}$ emissions to a level close to negligible (Zhang et al., 2010), as was also seen at Site 1 at ambient temperature less than $-9^{\circ} \mathrm{C}$ (Hu et al., 2014). On the other hand, $\mathrm{NH}_{3}$ emissions from industrial and/or non-industrial anthropogenic sources seemed to be enhanced in winter (Lillyman et al., 2009; Behera et al., 2013), as was supported by the 2-4 times higher mixing ratios of $\mathrm{SO}_{2}, \mathrm{HONO}$, and $\mathrm{HNO}_{3}$ in winter than in summer.

\subsection{Temporal variations of atmospheric $\mathrm{NH}_{3}$ at the eight American sites}

For the eight AMoN sites in the United States, the data measured from August 2008 to July 2015 were used for analysis at all the sites except at Site 12 for which the data measured during the period of September 2008-August 2015 were used (Fig. 3 and Table 1). Site 7 is located at an intensive agricultural activity zone in Randall, Texas, and Sites 8-10 are located in rural areas in Dodge, Wisconsin; Wayne, Michigan; 


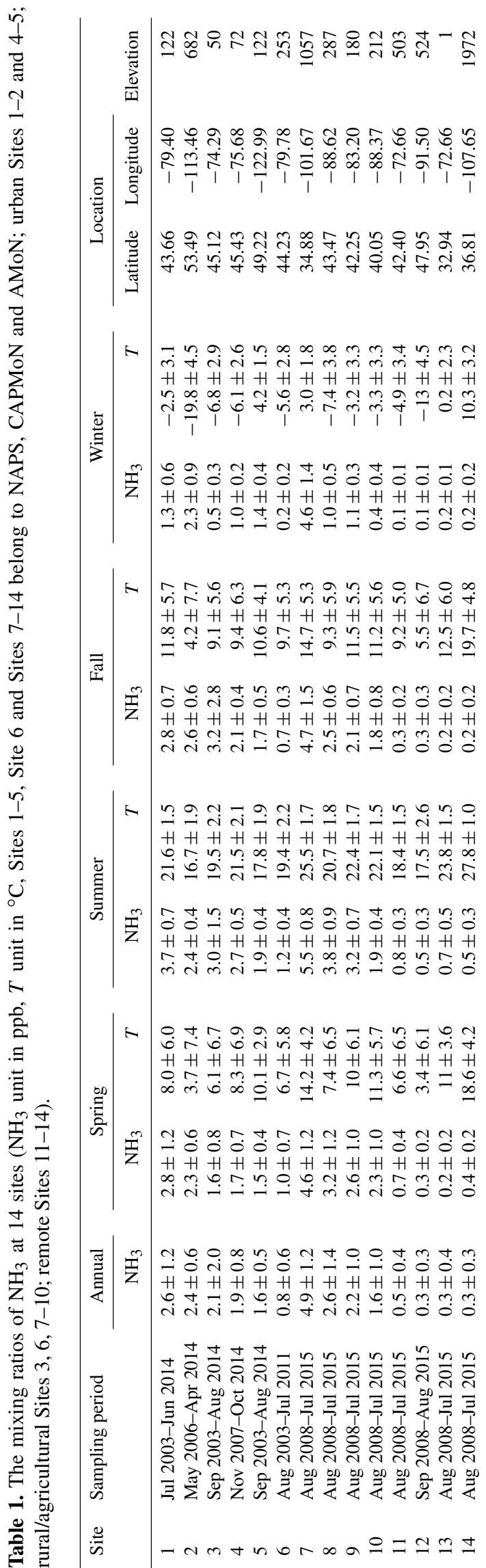

and Champaign, Illinois; respectively, with moderately intensive agricultural activities. Long-term average of $\mathrm{NH}_{3}$ was as high as $4.9 \pm 1.2 \mathrm{ppb}$ at Site 7 where the seasonal average in summer was approximately $20 \%$ higher than those in the other seasons. The $\mathrm{M}-\mathrm{K}$ analysis result showed an increasing trend at this site with a confidence level of $99.9 \%$. Longterm averages of $\mathrm{NH}_{3}$ at Sites 8-10 were $2.6 \pm 1.4,2.2 \pm 1.0$, and $1.6 \pm 1.0 \mathrm{ppb}$, respectively, and distinctive seasonal variations were seen at the three sites with the lowest values in winter. The $\mathrm{M}-\mathrm{K}$ analysis results showed an increasing trend at Sites $9-10$ with a confidence level of $>98 \%$ and no trend at Site 8.

Sites 11-14 are located in the remote areas in Tompkins, New York; Minnesota Lake, Minnesota; Charleston, South Carolina; and Rio Arriba, New Mexico, respectively. The long-term average $\mathrm{NH}_{3}$ was only $0.3-0.5 \mathrm{ppb}$ at these four remote sites but with distinctive seasonal variations with the highest in summer and the lowest in winter (Table 1). The $\mathrm{M}-\mathrm{K}$ analysis results showed an increasing trend at the four sites with a confidence level of $>95 \%$.

\subsection{Exponential correlations between $\mathrm{NH}_{3}$ and $T$}

When local soil and vegetation emissions were the major contributors to atmospheric $\mathrm{NH}_{3}$, its mixing ratio usually exhibited an exponential function of ambient $T$ (Sutton et al., 2009; Flechard et al., 2013; Hu et al., 2014). Thus, the exponential correlation relationship was examined at the 14 sites to identify potential major contributors to atmospheric $\mathrm{NH}_{3}$. Note that a perfect exponential correlation with $R^{2}>0.9$ would occur only when the soil-air mass transfer of $\mathrm{NH}_{3}$ was not the limitation factor (Flechard et al., 2013; Hu et al., 2014), and soil-air mass transfer rate associated with dry soil was much smaller (Su et al., 2011).

A moderately good exponential correlation was obtained at Site 1 with $R^{2}=0.74$ and $P$ value $<0.01$ (Fig. S2a). $\mathrm{NH}_{3}$ emissions from green space surrounding this site likely played a major role in the observed $\mathrm{NH}_{3}$ level (Hu et al., 2014). Similar results were obtained at Sites 3, 4, and 6 when a few exterior data points were excluded. For example, five data points at Site 3 severely deviate from the regression curve because of fertilizer application (Fig. S2c). When these five data points were excluded, $R^{2}$ reached 0.60 and $P$ value $<0.01$. In addition, $R^{2}$ was 0.75 at the rural Site 6 when one outlier data point was excluded (Fig. S2f). The two parameters in the regression equation $\left[\mathrm{NH}_{3}\right]=0.24 \times$ $\exp (0.094 \times T)$ were largely different from those obtained at the two downtown sites, i.e., $\left[\mathrm{NH}_{3}\right]=1.48 \times \exp (0.048 \times T)$ at Site 1 and $\left[\mathrm{NH}_{3}\right]=1.29 \times \exp (0.036 \times T)$ at Site 4 , noting that the parameters were close between the two downtown sites. Under the condition of $T$ below or close to $0^{\circ} \mathrm{C}$, the mixing ratios of atmospheric $\mathrm{NH}_{3}$ at the rural Site 6 were almost 1 order of magnitude smaller than those at the downtown sites, leading to the large difference for parameters in regression equations between the rural and urban sites. The 

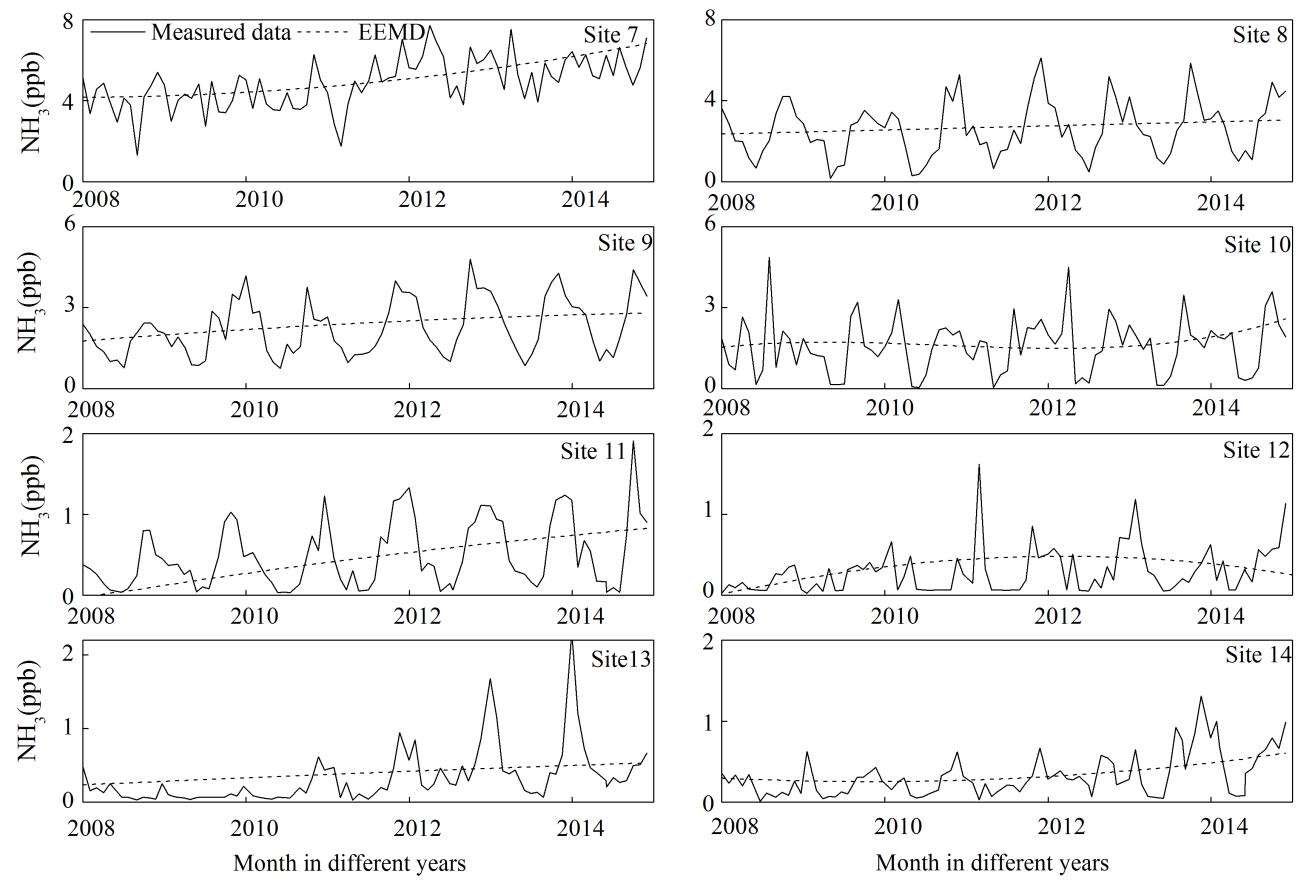

Figure 3. Monthly averages of measured atmospheric $\mathrm{NH}_{3}$ and its long-term trends extracted by the EEMD at eight US sites.

higher mixing ratio under freezing conditions at the Toronto downtown site was proposed to be likely associated with $\mathrm{NH}_{3}$ emissions from green space (Hu et al., 2014). Flechard et al. (2013) also reported higher $\mathrm{NH}_{3}$ mixing ratios over a grassland under freezing conditions, which could be due to slower dry deposition process and/or shallow boundary layer.

At Site 2, the exponential correlation was poor even with two outlier samples being excluded (Fig. S2b), implying that local soil and vegetation emissions were less likely the major contributors to atmospheric $\mathrm{NH}_{3}$. Like Site $2, R^{2}$ was only 0.39 at Site 5 even with two exterior data points being excluded (Fig. S2e). $\mathrm{NH}_{3}$ in urban atmospheres was reported to come from various sources (Whitehead et al., 2007; Ianniello et al., 2010; Saylor et al., 2010; Meng et al., 2011; Reche et al., 2012), some of which were less dependent on ambient $T$.

$R^{2}$ between atmospheric $\mathrm{NH}_{3}$ and ambient $T$ was below 0.1 at Site 7 (Fig. S3a). Considering the high mixing ratios observed at the rural/agricultural site, it can be confirmed that local agricultural emissions were the major contributor to atmospheric $\mathrm{NH}_{3}$ and the agricultural emissions appeared to be independent on ambient $T . R^{2}$ of $0.64,0.69$, and 0.45 at Sites 8-10, respectively (Fig. S3b-d), suggested that local soil and vegetation emissions should be among the major contributors to atmospheric $\mathrm{NH}_{3}$. The same can be said for the remote Site 11 with $R^{2}$ of 0.63 (Fig. S3e). $R^{2}$ was $0.25,0.2$, and 0.15 at remote Sites $12-14$ (Fig. S3f-i), respectively. When the data measured in calendar year 2011, 2012, 2013, and 2014 at Site 13 were used for correlation analysis, respectively, the values of $R^{2}$ were 0.47 in 2011 , 0.58 in 2012, 0.69 in 2013, and 0.74 in 2014. Local soil and vegetation emissions might be among the major contributors to atmospheric $\mathrm{NH}_{3}$ at the site while the low $R^{2}$ values in 2011-2012 could be due to analytical errors. In fact, the mixing ratios at the site in 2011-2012 were generally close to the detection limit. A similar calculation was conducted at Site 14 with $R^{2}$ still below 0.2 in different calendar years, suggesting that local soil and vegetation emissions were unlikely the major contributors to atmospheric $\mathrm{NH}_{3}$. Yao and Zhang (2013) proposed that long-range transport could be an important contributor to atmospheric $\mathrm{NH}_{3}$ at remote sites in North America. When a similar calculation was conducted at Site $12, R^{2}$ was 0.57 in 2012, 0.81 in 2013, and 0.39 in 2014. Local soil and vegetation emissions were possibly among the major contributors to atmospheric $\mathrm{NH}_{3}$ at the site in 2012 and 2013, but the long-range transport together with local soil and vegetation emissions might be important contributors to atmospheric $\mathrm{NH}_{3}$ in 2014.

\subsection{Cause analysis of trends in atmospheric $\mathrm{NH}_{3}$ at Canadian sites}

Site 1 is located in Downtown Toronto, Ontario. Figure S4a shows the annual anthropogenic $\mathrm{NH}_{3}$ emissions from 2003 to 2013 in Ontario, Canada. Not only the total $\mathrm{NH}_{3}$ emissions, but also emissions from the four major sectors including agricultural, mobile, industrial, and non-industrial generally decreased. However, an increasing trend in annual average $\mathrm{NH}_{3}$ was found at Site 1 , which was identified to be caused by (1) the increased $T$ and (2) the decreased $\mathrm{SO}_{2}$ emission. Increasing $T$ not only increases soil and vegeta- 
tion $\mathrm{NH}_{3}$ emissions but also favors more $\mathrm{NH}_{3}$ partitioning in the gas phase (Pinder et a., 2012; Sutton et al., 2013); both processes would increase $\mathrm{NH}_{3}$ mixing ratios. The decreased $\mathrm{SO}_{2}$ emissions due to the tightened emission control policies since 2008 by the city and provincial governments led to significant declines in $\mathrm{SO}_{2}$ oxidation products $(\mathrm{Hu}$ et al., 2014; Pugliese et al., 2014), which in turn also affected $\mathrm{NH}_{3}-\mathrm{pNH}_{4}^{+}$partitioning, the surface resistance for $\mathrm{NH}_{3}$, and increased $\mathrm{NH}_{3}$ mixing ratios (Yao et al., 2007; Fowler et al., 2015). These hypotheses were supported by the trends in $T$ and $\mathrm{pNH}_{4}^{+}$and their correlations with that in $\mathrm{NH}_{3}$, as detailed below.

A moderately good correlation $\left(R^{2}=0.76\right.$, $P$ value $<0.01)$ was obtained between the annual average $\mathrm{NH}_{3}$ and the annual average $T$, while a negative correlation $\left(R^{2}=0.40\right.$ and $P$ value $\left.<0.05\right)$ was obtained between the annual average $\mathrm{NH}_{3}$ and $\mathrm{pNH}_{4}^{+}$(Fig. 4a). Note that a decreasing trend in annual average $\mathrm{pNH}_{4}^{+}$was found with a confidence level of $>99 \%$ based on $\mathrm{M}-\mathrm{K}$ analysis. When ambient $T$ was increased by $5{ }^{\circ} \mathrm{C}$, the mixing ratio of atmospheric $\mathrm{NH}_{3}$ was increased by $\sim 1 \mathrm{ppb}$ according to the regression equation. The annual average $T$ shown in Fig. 4 was calculated from the daily averaged values of $T$ on the sampling days when valid $\mathrm{NH}_{3}$ data were available, not every day of the year, and thus might be different from the actual annual average $T$. The moderately good correlation between the annual average values of $\mathrm{NH}_{3}$ and ambient temperature might be coincident. This is also supported by the decreasing correlation when the EEMD-extracted results were used for calculation as presented below.

Figure S5 shows the intrinsic mode functions (IMFs) and residuals solved by the EEMD at Site 1. The extracted residuals represented the long-term trend in atmospheric $\mathrm{NH}_{3}$, and the IMFs represented other fluctuations in different timescales. The EEMD-extracted long-term trend in atmospheric $\mathrm{NH}_{3}$ was generally increased by $\sim 20 \%$ from 2003 to 2014. The EEMD was also used to extract the long-term trend in $\mathrm{pNH}_{4}^{+}$in $\mathrm{PM}_{2.5}$ from 2003 to 2014 (Fig. S6). Correlation between the two EEMD-extracted long-term trends resulted in a regression equation of $\left[\mathrm{NH}_{3}\right]=-1.41 \times\left[\mathrm{pNH}_{4}^{+}\right]+$ 4.3, with $R^{2}=0.93$ and $P$ value $<0.01$ (Fig. 4b). The unit of $\mathrm{NH}_{3}$ is in ppb while the unit of $\mathrm{pNH}_{4}^{+}$is in $\mu \mathrm{g} \mathrm{m}^{-3}$. The absolute value of the regression slope was almost the same as the unit conversion coefficient. Thus, the EEMD-extracted long-term trend in atmospheric $\mathrm{NH}_{3}$ seemed to be mainly determined by the change in $\mathrm{NH}_{3}-\mathrm{pNH}_{4}^{+}$partitioning. The increasing $T$ further enhanced this trend. When the EEMDextracted long-term trend in ambient $T$ was correlated to that of atmospheric $\mathrm{NH}_{3}$, we obtained $\left[\mathrm{NH}_{3}\right]=0.13 \times T+$ $1.5, R^{2}=0.47$ and $P$ value $<0.01$ (Fig. 4b). The EEMDextracted results suggest that the change in $\mathrm{NH}_{3}-\mathrm{NH}_{4}^{+}$partitioning is one of the dominant factors influencing the longterm $\mathrm{NH}_{3}$ trend at Site 1. The relative importance between (1) changes in $\mathrm{NH}_{3}-\mathrm{NH}_{4}^{+}$partitioning and (2) increased bio-
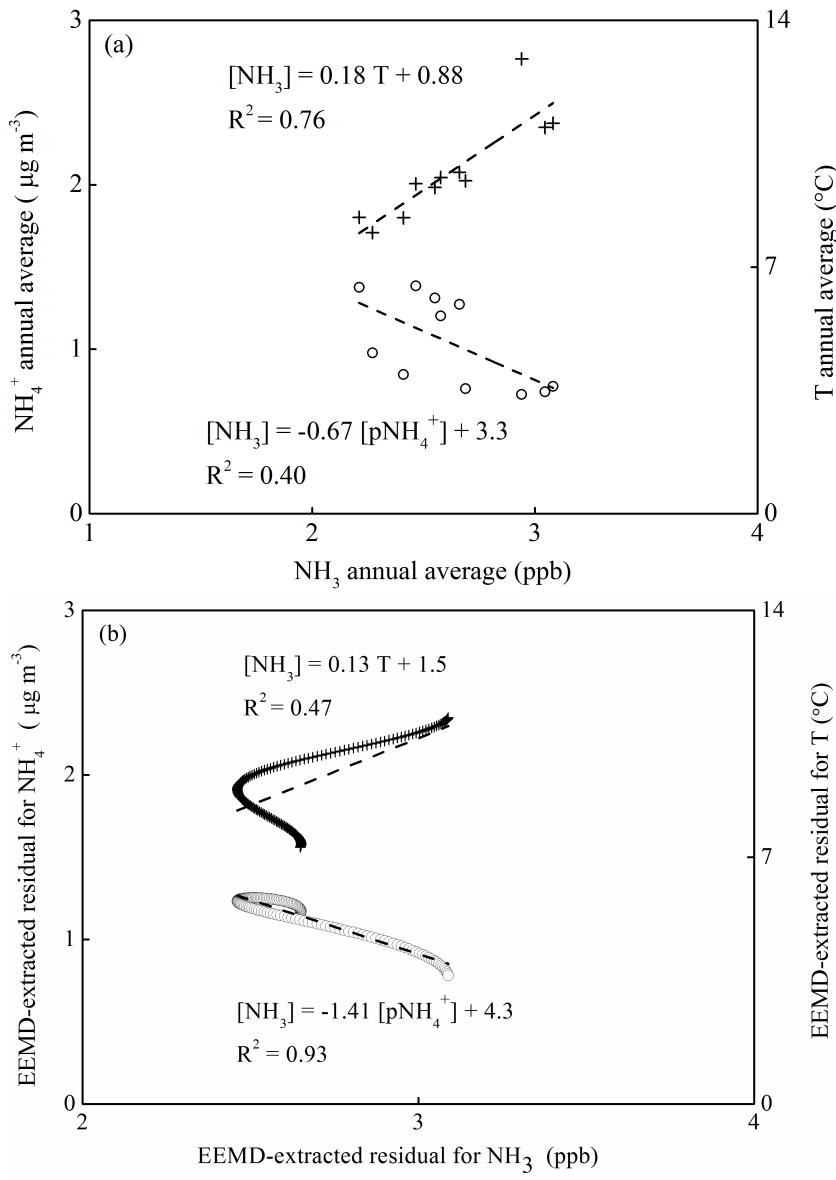

Figure 4. Correlations between atmospheric $\mathrm{NH}_{3}$ and ambient $T$ at Site 1 (a: annual average value; b: EEMD-extracted trend).

genic $\mathrm{NH}_{3}$ emission due to increasing $T$ is yet to be investigated.

At Site 2, the EEMD-extracted residual of atmospheric $\mathrm{NH}_{3}$ varied within a very small range ( $\sim 10 \%$, Fig. 2$)$, which was consistent with stable trend generated from the $\mathrm{M}-\mathrm{K}$ analysis. Little correlation was found between the annual average $\mathrm{NH}_{3}$ and $T\left(R^{2}<0.05\right)$ or $\mathrm{pNH}_{4}^{+}\left(R^{2}<0.01\right)$. Thus, the $\mathrm{NH}_{3}$ trend identified at Site 2 was seemingly unaffected by changes in $\mathrm{NH}_{3}-\mathrm{NH}_{4}^{+}$partitioning and $T$-dependent biogenic $\mathrm{NH}_{3}$ emission, or additional local factors canceled out the impact from the two factors.

Site 3 is a rural/agricultural site and annual agricultural $\mathrm{NH}_{3}$ emissions in Québec were stable from 2003 to 2009 with a CV of 0.02 (Fig. S4c). During the same period, mobile, industrial, and non-industrial emissions were decreased by $40 \%$ in Québec. While the $\mathrm{M}-\mathrm{K}$ analysis result showed no consistent long-term trend in atmospheric $\mathrm{NH}_{3}$, the EEMD-extracted a bell-shaped pattern (Fig. 2). That is, $\mathrm{NH}_{3}$ increased from $1.7 \mathrm{ppb}$ in 2003 to $2.5 \mathrm{ppb}$ in 2009 and then decreased down to $1.3 \mathrm{ppb}$ in 2014 . The anthropogenic $\mathrm{NH}_{3}$ emission data from 2003 to 2009 did not support the 
increasing trend in atmospheric $\mathrm{NH}_{3}$ at this site during this period. However, Sintermann et al. (2012) reported that $\mathrm{NH}_{3}$ emission factors highly depend on meteorology and efficiencies of technical controls on $\mathrm{NH}_{3}$ emission processes. $\mathrm{NH}_{3}$ emission factors adopted in $\mathrm{NH}_{3}$ emission inventories may suffer from uncertainties to some extent, which in turn may transfer to the estimated $\mathrm{NH}_{3}$ emission and affect its relationship with the observed atmospheric $\mathrm{NH}_{3}$.

A good correlation was found between the EEMDextracted long-term trends in $\mathrm{NH}_{3}$ and $T$ with a linear regression relationship of $\left[\mathrm{NH}_{3}\right]=0.39 \times T-0.30$, with $R^{2}=0.80$ and $P$ value $<0.01$. The slope of 0.39 was consistent with that reported by Sutton et al. (2013). That is, $\mathrm{NH}_{3}$ volatilization potential nearly doubles every $5^{\circ} \mathrm{C}$. On the contrary, little correlation was found between the EEMD-extracted residuals for atmospheric $\mathrm{NH}_{3}$ and $\mathrm{pNH}_{4}^{+}\left(R^{2}<0.1\right)$, suggesting that the $\mathrm{NH}_{3}-\mathrm{pNH}_{4}^{+}$partitioning likely played a negligible role on the long-term trend in atmospheric $\mathrm{NH}_{3}$ at this site.

A similar conclusion could also be generated for Site 4 to that for Site 3. The $\mathrm{M}-\mathrm{K}$ analysis results showed a stable trend in atmospheric $\mathrm{NH}_{3}$ and a slightly decreasing trend in $\mathrm{pNH}_{4}^{+}$with a confidence level of $>99 \%$. The EEMDextracted long-term trend showed that $\mathrm{NH}_{3}$ decreased by $\sim 5 \%$ from 2007 to 2008 and then increased by $\sim 50 \%$ afterwards. Although the correlation between the annual averages $\mathrm{NH}_{3}$ and $T$ was not very $\operatorname{good}\left(R^{2}=0.39, P=0.13\right)$, correlation between the EEMD-extracted long-term trends in $\mathrm{NH}_{3}$ and $T$ was almost perfect $\left(R^{2}=0.90, P<0.01\right)$. No correlation was found between the annual average $\mathrm{NH}_{3}$ and $\left[\mathrm{pNH}_{4}^{+}\right]$ $\left(R^{2}<0.01\right)$, and a relatively low correlation was found between the EEMD-extracted long-term trends in atmospheric $\mathrm{NH}_{3}$ and $\mathrm{pNH}_{4}^{+}\left(R^{2}=0.39, P\right.$ value $\left.<0.01\right)$. These results suggested that the long-term change in ambient $T$ possibly affected the long-term trend in atmospheric $\mathrm{NH}_{3}$ at the site. However, longer measurements are still needed to confirm the trends in atmospheric $\mathrm{NH}_{3}$ and ambient $T$ as well as their relationship at the site because of the inherent weaknesses in this data set, such as only 7 years and only one $24 \mathrm{~h}$ sample every 3 days available data, and some missing data during this period.

Site 5 is an urban site located in British Columbia, Canada. Anthropogenic $\mathrm{NH}_{3}$ emissions were decreased from 2003 to 2013 in this province (Fig. S4c). The M-K analysis result showed no trend in atmospheric $\mathrm{NH}_{3}$ at Site 5 from 2003 to 2014, and the EEMD-extracted long-term trend was almost constant. We conducted the correlation analysis of the EEMD-extracted results and found that the long-term changes in ambient $T$ and $\mathrm{pNH}_{4}^{+}$cannot explain the EEMDextracted trend in atmospheric $\mathrm{NH}_{3}$ at this site.

At Site 6, the EEMD-extracted trend in atmospheric $\mathrm{NH}_{3}$ showed an increase of $\sim 10 \%$ from 2003 to 2006 and then a decrease of $\sim 40 \%$ afterwards (Fig. 2). Poor correlations were found between annual average $\mathrm{NH}_{3}$ and $T$ or between
$\mathrm{NH}_{3}$ and $\mathrm{NH}_{4}^{+}$with $P$ values $>0.05$. Meaningless correlations between the EEMD-extracted trends in $\mathrm{NH}_{3}$ and $T$ or between the EEMD-extracted trends in $\mathrm{NH}_{3}$ and $\mathrm{NH}_{4}^{+}$were obtained. The trend in $T$ and $\mathrm{NH}_{3}-\mathrm{NH}_{4}^{+}$partitioning cannot explain the long-term variations of atmospheric $\mathrm{NH}_{3}$.

\subsection{Cause analysis of trends in atmospheric $\mathrm{NH}_{3}$ at the US sites}

At the eight US sites, $R^{2}$ values between annual average $\mathrm{NH}_{3}$ and $T$ were all below 0.2 with $P$ values all larger than 0.1 . The simple correlation analysis did not provide direct evidence that $T$ was the significant factor affecting the $\mathrm{NH}_{3}$ trend. However, the EEMD-extracted trends in $\mathrm{NH}_{3}$ and $T$ had a much better correlation at some sites, e.g., with $R^{2}=0.85,0.99,0.54$, and 0.99 at Sites $7,8,9$, and 13, respectively, and with $P$ values smaller than 0.01 . Thus, the increasing $T$ was likely one of important factors causing the long-term trend in $\mathrm{NH}_{3}$ at these four sites. Note that no reasonable relationship was identified between trends in $\mathrm{NH}_{3}$ and $T$ at the other four sites using the EEMD method.

The EEMD-extracted long-term trend showed an increase in atmospheric $\mathrm{NH}_{3}$ from $4.2 \mathrm{ppb}$ in August 2008 to $6.8 \mathrm{ppb}$ in July 2015 at Site 7 (Fig. 3a), from 2.4 ppb in August of 2008 to $3.0 \mathrm{ppb}$ in July of 2015 at Site 8 (Fig. 3b), from $1.8 \mathrm{ppb}$ in August of 2008 to $2.8 \mathrm{ppb}$ in July of 2015 at Site 9 (Fig. 3c), a complex varying pattern during the period from August 2008 to July 2015 at Site 10 (Fig. 3d), and an increasing trend (by $0.3-0.5 \mathrm{ppb}$, or $100-200 \%$ in percentages) at Sites 11-14 (Fig. 3e-h). The percentage increases (100-200\%) in $\mathrm{NH}_{3}$ mixing ratio from 2008 to 2015 at the remote sites were substantially larger than those at the rural/agricultural sites (20-50\%).

$\mathrm{NH}_{3}$ emissions in the United States increased by $11 \%$ during the period from 1990 to 2010 due to the growth of livestock activities (Xing et al., 2013). This is particularly the case in North Carolina and Iowa. This increase alone is not enough to explain the $\sim 50 \%$ increase in $\mathrm{NH}_{3}$ from 2008 to 2015 at Site 7, which is located in Texas. The increased $T$ is possibly another important factor causing the increased $\mathrm{NH}_{3}$ at this site, as mentioned above. It is also noted that the increasing trends in $\mathrm{NH}_{3}$ at Sites 11-14 identified using the EEMD-extracted results were also consistent with the M-K analysis results.

The annual average $\mathrm{NH}_{3}$ at the remote sites reached 0.4$0.6 \mathrm{ppb}$ in 2015 . Assuming the same increasing rate continues for another 7-10 years, the annual average will exceed the proposed critical level of $1 \mu \mathrm{g} \mathrm{m}^{-3}$ at two sites for protecting sensitive ecosystems (Cape et al., 2009).

\section{Conclusions}

Long-term average of atmospheric $\mathrm{NH}_{3}$ was in the range of $0.3-0.5,1.6-2.6$, and $0.8-4.9 \mathrm{ppb}$ at the remote, ur- 
ban, and rural/agricultural sites across North America, respectively. Moderate exponential correlations between atmospheric $\mathrm{NH}_{3}$ and ambient $T$ were found at nine sites, implying that local biogenic emissions and/or $\mathrm{NH}_{3}-\mathrm{NH}_{4}^{+}$partitioning were likely important factors causing the long-term trends in atmospheric $\mathrm{NH}_{3}$ at these sites. However, the length of the used data covers only 7-11 years, and further examination is needed for the trend analysis when more data of atmospheric $\mathrm{NH}_{3}$ are available.

No decreasing trends in atmospheric $\mathrm{NH}_{3}$ were found at the four Canadian sites despite significant decreases in anthropogenic $\mathrm{NH}_{3}$ emissions from main sectors in the last decade. The decreased $\mathrm{NH}_{3}$ anthropogenic emission was compensated for or overwhelmed by the increased biogenic emission, changes in $\mathrm{NH}_{3}-\mathrm{NH}_{4}^{+}$partitioning, and/or the increased surface resistance for $\mathrm{NH}_{3}$ because of the less acidic surface associated with less $\mathrm{SO}_{2}$ dry deposition. This was supported by $\mathrm{pNH}_{4}^{+}$data which exhibited a decreasing trend, likely caused by a combination of reduced $\mathrm{SO}_{2}$ and $\mathrm{NO}_{x}$ emission and increased temperature. No decreasing trends in atmospheric $\mathrm{NH}_{3}$ were found at other two Canadian sites, but it was unknown what caused this phenomenon. Uncertainties in the $\mathrm{NH}_{3}$ emission inventory are still a concern and may affect the trend analysis results of the relationship between atmospheric $\mathrm{NH}_{3}$ and $\mathrm{NH}_{3}$ emissions.

The $\mathrm{M}-\mathrm{K}$ analysis showed an increasing trend in atmospheric $\mathrm{NH}_{3}$ at seven out of the eight US sites, which was also supported by the EEMD-extracted results. $\mathrm{NH}_{3}$ increased by $20-50 \%$ from 2008 to 2015 at the three rural/agricultural sites and by $100-200 \%$ at the four remote sites. If the same increasing trend continues in the next 57 years, the annual average $\mathrm{NH}_{3}$ at two remote sites will exceed $1 \mu \mathrm{g} \mathrm{m}^{-3}$, a level below which has been proposed to protect sensitive ecosystems at the remote sites.

In most cases, the two statistical approaches used in the present study yield consistent trends in atmospheric $\mathrm{NH}_{3}$ measured at different sites. The EEMD method appeared to have more powerful interpretation ability for resolving trends because (1) it is less affected by extremely high concentration points, and (2) it yields a continuous and quantitative trend result. However, this method occasionally suffers from "the end effect" and leads to physically meaningless results. Using the combined approach (or more than one statistical methods) can better resolve and interpret long-term trends in atmospheric $\mathrm{NH}_{3}$.

\section{Data availability}

The emission date of $\mathrm{NH}_{3}$ can be downloaded at the link http://www.ec.gc.ca/inrp-npri/default.asp?lang=En\&n= 4A577BB9-1 (NPRI, 2016). The data of atmospheric $\mathrm{NH}_{3}$ measured by the Canadian National Air Pollution Surveillance (NAPS) can be downloaded from http://www. ec.gc.ca/rnspa-naps/ (NAPS, 2016). The data of atmo- spheric $\mathrm{NH}_{3}$ measured by the Canadian Air and Precipitation Monitoring Network (CAPMoN) can be downloaded from http://www.ec.gc.ca/natchem/default.asp?lang=En\&n= 90EDB4BC-1 (CAPMoN, 2016) by sending a request email to national.atmospheric.chemistry.ontario@ec.gc.ca; The data of atmospheric $\mathrm{NH}_{3}$ measured by the US Passive Ammonia Monitoring Network can be downloaded from http://nadp.sws.uiuc.edu/AMoN (Gay et al., 2016).

\section{The Supplement related to this article is available online at doi:10.5194/acp-16-11465-2016-supplement.}

Acknowledgements. Ammonia Monitoring Network (http://nadp.sws.uiuc.edu/data/sites/list/?net=AMoN) is acknowledged for allowing the use of the data for analysis conducted in this study. The work is financially supported by the Clear Air Regulatory Agenda of Canada and Xiaohong Yao thanks the support from the National Program on Key Basic Research Project (973 Program: 2014CB953700) of China.

Edited by: F. Yu

Reviewed by: C. R. Flechard and one anonymous referee

\section{References}

Alebic-Juretic, A.: Airborne ammonia and ammonium within the Northern Adriatic area, Croatia, Environ. Pollut., 154, 439-447, doi:10.1016/j.envpol.2007.11.029, 2008.

Beem, K. B., Raja, S., Schwandner, F. M., Taylor, C., Lee, T., Sullivan, A. P., Carrico, C. M., McMeeking, G. R., Day, D., and Levin, E.: Deposition of reactive nitrogen during the Rocky Mountain Airborne Nitrogen and Sulfur (RoMANS) study, Environ. Pollut., 158, 862-872, doi:10.1016/j.envpol.2009.09.023, 2010.

Behera, S. N., Sharma, M., Aneja, V. P., and Balasubramanian, R.: Ammonia in the atmosphere: a review on emission sources, atmospheric chemistry and deposition on terrestrial bodies, Environ. Sci. Pollut. R., 20, 8092-8131, doi:10.1007/s11356-0132051-9, 2013.

Bishop, G. A., Peddle, A. M., Stedman, D. H., and Zhan, T.: Onroad emission measurements of reactive nitrogen compounds from three California cities, Environ. Sci. Technol., 44, 36163620, doi:10.1021/es903722p, 2010.

Bobbink, R., Hicks, K., Galloway, J., Spranger, T., Alkemade, R., Ashmore, M., Bustamante, M., Cinderby, S., Davidson, E., and Dentener, F.: Global assessment of nitrogen deposition effects on terrestrial plant diversity: a synthesis, Ecol. Appl., 20, 30-59, doi:10.1890/08-1140.1, 2010.

Canadian Air and Precipitation Monitoring Network (CAPMoN): The NAtChem Data, data updated annually, available at: http://www.ec.gc.ca/natchem/default.asp?lang=En\&n= 90EDB4BC-1, last access: 12 September 2016. 
Cape, J. N., Van der Eerden, L. J., Sheppard, L. J., Leith, I. D., and Sutton, M. A.: Evidence for changing the critical level for ammonia, Environ. Pollut., 157, 1033-1037, doi:10.1016/j.envpol.2008.09.049, 2009.

Dabek-Zlotorzynska, E., Dann, T. F., Martinelango, P. K., Celo, V., Brook, J. R., Mathieu, D., Ding, L., and Austin, C. C.: Canadian National Air Pollution Surveillance (NAPS) $\mathrm{PM}_{2.5}$ speciation program: methodology and $\mathrm{PM}_{2.5}$ chemical composition for the years 2003-2008, Atmos. Environ., 45, 673-686, doi:10.1016/j.atmosenv.2010.10.024, 2011.

Day, D. E., Chen, X., Gebhart, K. A., Carrico, C. M., Schwandner, F. M., Benedict, K. B., Schichtel, B. A., and Collett, J. L.: Spatial and temporal variability of ammonia and other inorganic aerosol species, Atmos. Environ., 61, 490-498, doi:10.1016/j.atmosenv.2012.06.045, 2012.

Ellis, R. A., Murphy, J. G., Markovic, M. Z., VandenBoer, T. C., Makar, P. A., Brook, J., and Mihele, C.: The influence of gasparticle partitioning and surface-atmosphere exchange on ammonia during BAQS-Met, Atmos. Chem. Phys., 11, 133-145, doi:10.5194/acp-11-133-2011, 2011.

Erisman, J. W., Bleeker, A., Galloway, J., and Sutton, M. S.: Reduced nitrogen in ecology and the environment, Environ. Pollut., 150, 140-149, doi:10.1016/j.envpol.2007.06.033, 2007.

Erturk, A., Gullu, M. K., and Erturk, S.: Hyperspectral image classification using empirical mode decomposition with spectral gradient enhancement, IEEE T. Geosci. Remote, 51, 2787-2798, doi:10.1109/TGRS.2012.2217501, 2013.

Ferm, M. and Hellsten, S.: Trends in atmospheric ammonia and particulate ammonium concentrations in Sweden and its causes, Atmos. Environ., 61, 30-39, doi:10.1016/j.atmosenv.2012.07.010, 2012.

Flechard, C. R., Massad, R.-S., Loubet, B., Personne, E., Simpson, D., Bash, J. O., Cooter, E. J., Nemitz, E., and Sutton, M. A.: Advances in understanding, models and parameterizations of biosphere-atmosphere ammonia exchange, Biogeosciences, 10, 5183-5225, doi:10.5194/bg-10-5183-2013, 2013.

Fowler, D., Steadman, C. E., Stevenson, D., Coyle, M., Rees, R. M., Skiba, U. M., Sutton, M. A., Cape, J. N., Dore, A. J., Vieno, M., Simpson, D., Zaehle, S., Stocker, B. D., Rinaldi, M., Facchini, M. C., Flechard, C. R., Nemitz, E., Twigg, M., Erisman, J. W., Butterbach-Bahl, K., and Galloway, J. N.: Effects of global change during the 21st century on the nitrogen cycle, Atmos. Chem. Phys., 15, 13849-13893, doi:10.5194/acp-1513849-2015, 2015.

Gay, D., Claybrooke, R., Larson, B., Rhodes, M., Volk, L., and Lehmann, C.: Ammonia Monitoring Network (AMoN), National Atmospheric Deposition Program, data updated monthly or bimonthly, US Passive Ammonia Monitoring Network, available at: http://nadp.sws.uiuc.edu/AMoN, last access: 12 September 2016.

Gilbert, R. O.: Statistical Methods for Environmental Pollution Monitoring, John Wiley \& Sons, New York, USA, 1987.

Hand, J. L., Schichtel, B. A., Pitchford, M., Malm, W. C., and Frank, N. H.: Seasonal composition of remote and urban fine particulate matter in the United States, J. Geophys. Res.-Atmos., 117, D05209, doi:10.1029/2011JD017122, 2012.

Hu, Q., Zhang, L., Evans, G. J., and Yao, X.: Variability of atmospheric ammonia related to potential emission sources in downtown Toronto, Canada, Atmos. Environ., 99, 365-373, doi:10.1016/j.atmosenv.2014.10.006, 2014.

Ianniello, A., Spataro, F., Esposito, G., Allegrini, I., Rantica, E., Ancora, M. P., Hu, M., and Zhu, T.: Occurrence of gas phase ammonia in the area of Beijing (China), Atmos. Chem. Phys., 10, 9487-9503, doi:10.5194/acp-10-9487-2010, 2010.

Ianniello, A., Spataro, F., Esposito, G., Allegrini, I., Hu, M., and Zhu, T.: Chemical characteristics of inorganic ammonium salts in $\mathrm{PM}_{2.5}$ in the atmosphere of Beijing (China), Atmos. Chem. Phys., 11, 10803-10822, doi:10.5194/acp-11-10803-2011, 2011.

Kampata, J. M., Parida, B. P., and Moalafhi, D. B.: Trend analysis of rainfall in the headstreams of the Zambezi River Basin in Zambia, Phys. Chem. Earth., 33, 621-625, doi:10.1016/j.pce.2008.06.012, 2008.

Krupa, S. V.: Effects of atmospheric ammonia $\left(\mathrm{NH}_{3}\right)$ on terrestrial vegetation: a review, Environ. Pollut., 124, 179-221, doi:10.1016/S0269-7491(02)00434-7, 2003.

Kulmala, M., Vehkamäki, H., Petäjä, T., Dal Maso, M., Lauri, A., Kerminen, V., Birmili, W., and McMurry, P. H.: Formation and growth rates of ultrafine atmospheric particles: a review of observations, J. Aerosol. Sci., 35, 143-176, doi:10.1016/j.jaerosci.2003.10.003, 2004.

Lillyman, C., Buset, K., and Mullins, D.: Canadian Atmospheric Assessment of Agricultural Ammonia, National AgriEnvironmental Standards, Environment Canada, Gatineau, Quebec, Canada, 2009.

Markovic, M. Z., VandenBoer, T. C., Baker, K. R., Kelly, J. T., and Murphy, J. G.: Measurements and modeling of the inorganic chemical composition of fine particulate matter and associated precursor gases in California's San Joaquin Valley during CalNex 2010, J. Geophys. Res.-Atmos., 119, 6853-6866, doi:10.1002/2013JD021408, 2014.

Meng, Z. Y., Lin, W. L., Jiang, X. M., Yan, P., Wang, Y., Zhang, Y. M., Jia, X. F., and Yu, X. L.: Characteristics of atmospheric ammonia over Beijing, China, Atmos. Chem. Phys., 11, 61396151, doi:10.5194/acp-11-6139-2011, 2011

National Air Pollution Surveillance Program (NAPS): Atmospheric $\mathrm{NH}_{3}$, data updated monthly or bi-monthly, available at: http:// www.ec.gc.ca/rnspa-naps/, last access: 12 September 2016.

Nowak, J. B., Neuman, J. A., Bahreini, R., Middlebrook, A. M., Holloway, J. S., McKeen, S. A., Parrish, D. D., Ryerson, T. B., and Trainer, M.: Ammonia sources in the California South Coast Air Basin and their impact on ammonium nitrate formation, Geophys. Res. Lett., 39, L07804, doi:10.1029/2012GL051197, 2012.

National Pollutant Release Inventory (NPRI): Emission date of $\mathrm{NH}_{3}$, data update annually, available at: http://www.ec.gc. ca/inrp-npri/default.asp?lang=En\&n=4A577BB9-1, last access: 12 September 2016.

Paulot, F. and Jacob, D. J.: Hidden cost of US agricultural exports: particulate matter from ammonia emissions, Environ. Sci. Technol., 48, 903-908, doi:10.1021/es4034793, 2014.

Pinder, R. W., Davidson, E. A., Goodale, C. L., Greaver, T. L., Herrick, J. D., and Liu, L.: Climate change impacts of US reactive nitrogen, P. Natl. Acad. Sci. USA, 109, 7671-7675, doi:10.1073/pnas.1114243109, 2012.

Puchalski, M. A., Rogers, C. M., Baumgardner, R., Mishoe, K. P., Price, G., Smith, M. J., Watkins, N., and Lehmann, C. M.: A statistical comparison of active and passive ammonia measurements collected at Clean Air Status and Trends Net- 
work (CASTNET) sites, Environ. Sci.-Proc. Imp., 17, 358-369, doi:10.1039/c4em00531g, 2015.

Pugliese, S. C., Murphy, J. G., Geddes, J. A., and Wang, J. M.: The impacts of precursor reduction and meteorology on groundlevel ozone in the Greater Toronto Area, Atmos. Chem. Phys., 14, 8197-8207, doi:10.5194/acp-14-8197-2014, 2014.

Pye, H., Liao, H., Wu, S., Mickley, L. J., Jacob, D. J., Henze, D. K., and Seinfeld, J. H.: Effect of changes in climate and emissions on future sulfate-nitrate-ammonium aerosol levels in the United States, J. Geophys. Res.-Atmos., 114, D01205, doi:10.1029/2008JD010701, 2009.

Reche, C., Viana, M., Pandolfi, M., Alastuey, A., Moreno, T., Amato, F., Ripoll, A., and Querol, X.: Urban $\mathrm{NH}_{3}$ levels and sources in a Mediterranean environment, Atmos. Environ., 57, 153-164, doi:10.1016/j.atmosenv.2012.04.021, 2012.

Ren, H., Wang, Y., Huang, M., Chang, Y., and Kao, H.: Ensemble empirical mode decomposition parameters optimization for spectral distance measurement in hyperspectral remote sensing data, Remote Sens., 6, 2069-2083, doi:10.3390/rs6032069, 2014.

Saylor, R. D., Edgerton, E. S., Hartsell, B. E., Baumann, K., and Hansen, D. A.: Continuous gaseous and total ammonia measurements from the southeastern aerosol research and characterization (SEARCH) study, Atmos. Environ., 44, 4994-5004, doi:10.1016/j.atmosenv.2010.07.055, 2010.

Schiferl, L. D., Heald, C. L., Nowak, J. B., Holloway, J. S., Neuman, J. A., Bahreini, R., Pollack, I. B., Ryerson, T. B., Wiedinmyer, C., and Murphy, J. G.: An investigation of ammonia and inorganic particulate matter in California during the CalNex campaign, J. Geophys. Res.-Atmos., 119, 1883-1902, doi:10.1002/2013JD020765, 2014.

Sintermann, J., Neftel, A., Ammann, C., Häni, C., Hensen, A., Loubet, B., and Flechard, C. R.: Are ammonia emissions from fieldapplied slurry substantially over-estimated in European emission inventories?, Biogeosciences, 9, 1611-1632, doi:10.5194/bg-91611-2012, 2012.

Su, H., Cheng, Y., Oswald, R., Behrendt, T., Trebs, I., Meixner, F. X., Andreae, M. O., Cheng, P., Zhang, Y., and Pöschl, U.: Soil nitrite as a source of atmospheric $\mathrm{HONO}$ and $\mathrm{OH}$ radicals, Science, 333, 1616-1618, doi:10.1126/science.1207687, 2011.

Sutton, M. A., Nemitz, E., Theobald, M. R., Milford, C., Dorsey, J. R., Gallagher, M. W., Hensen, A., Jongejan, P. A. C., Erisman, J. W., Mattsson, M., Schjoerring, J. K., Cellier, P., Loubet, B., Roche, R., Neftel, A., Hermann, B., Jones, S. K., Lehman, B. E., Horvath, L., Weidinger, T., Rajkai, K., Burkhardt, J., Löpmeier, F. J., and Daemmgen, U.: Dynamics of ammonia exchange with cut grassland: strategy and implementation of the GRAMINAE Integrated Experiment, Biogeosciences, 6, 309331, doi:10.5194/bg-6-309-2009, 2009.

Sutton, M. A., Reis, S., Riddick, S. N., Dragosits, U., Nemitz, E., Theobald, M. R., Tang, Y. S., Braban, C. F., Vieno, M., and Dore, A. J.: Towards a climate-dependent paradigm of ammonia emission and deposition, Philos. T. Roy. Soc. B, 368, 20130166 , doi:10.1098/rstb.2013.0166, 2013.

Theobald, M. R., Løfstrøm, P., Walker, J., Andersen, H. V., Pedersen, P., Vallejo, A., and Sutton, M. A.: An intercomparison of models used to simulate the short-range atmospheric dispersion of agricultural ammonia emissions, Environ. Modell. Softw., 37, 90-102, doi:10.1016/j.envsoft.2012.03.005, 2012.
Van Damme, M., Clarisse, L., Heald, C. L., Hurtmans, D., Ngadi, Y., Clerbaux, C., Dolman, A. J., Erisman, J. W., and Coheur, P. F.: Global distributions, time series and error characterization of atmospheric ammonia $\left(\mathrm{NH}_{3}\right)$ from IASI satellite observations, Atmos. Chem. Phys., 14, 2905-2922, doi:10.5194/acp-14-29052014, 2014.

Walker, J. M., Philip, S., Martin, R. V., and Seinfeld, J. H.: Simulation of nitrate, sulfate, and ammonium aerosols over the United States, Atmos. Chem. Phys., 12, 11213-11227, doi:10.5194/acp12-11213-2012, 2012.

Walker, J. T., Aneja V. P., and Dickey D. A.: Atmospheric transport and wet deposition of ammonium in North Carolina, Atmos. Environ., 34, 3407-3418, doi:10.1016/S1352-2310(99)00499-9, 2000.

Whitehead, J. D., Longley, I. D., and Gallagher, M. W.: Seasonal and diurnal variation in atmospheric ammonia in an urban environment measured using a quantum cascade laser absorption spectrometer, Water Air Soil Pollut., 183, 317-329, doi:10.1007/s11270-007-9381-5, 2007.

Wu, Z. and Huang, N. E.: Ensemble empirical mode decomposition: a noise-assisted data analysis method, Adv. Adapt. Data Anal., 1, 1-41, 2009.

Xing, J., Pleim, J., Mathur, R., Pouliot, G., Hogrefe, C., Gan, C.-M., and Wei, C.: Historical gaseous and primary aerosol emissions in the United States from 1990 to 2010, Atmos. Chem. Phys., 13, 7531-7549, doi:10.5194/acp-13-7531-2013, 2013.

Yao, X., Ling, T. Y., Fang, M., and Chan, C. K.: Size dependence of in situ $\mathrm{pH}$ in submicron atmospheric particles in Hong Kong. Atmos. Environ., 41, 382-393, doi:10.1016/j.atmosenv.2006.07.037, 2007.

Yao, X., Hu, Q., Zhang, L., Evans, G. J., Godri, K. J., and Ng, A. C.: Is vehicular emission a significant contributor to ammonia in the urban atmosphere?, Atmos. Environ., 80, 499-506, doi:10.1016/j.atmosenv.2013.08.028, 2013.

Yao, X. H. and Zhang, L.: Supermicron modes of ammonium ions related to fog in rural atmosphere, Atmos. Chem. Phys., 12, 11165-11178, doi:10.5194/acp-12-11165-2012, 2012.

Yao, X. H. and Zhang, L.: Analysis of passive-sampler monitored atmospheric ammonia at 74 sites across southern Ontario, Canada, Biogeosciences, 10, 7913-7925, doi:10.5194/bg10-7913-2013, 2013.

Zbieranowski, A. L. and Aherne, J.: Long-term trends in atmospheric reactive nitrogen across Canada: 1988-2007, Atmos. Environ., 45, 5853-5862, doi:10.1016/j.atmosenv.2011.06.080, 2011.

Zhang, L., Wright, L. P., and Asman, W.: Bi-directional air-surface exchange of atmospheric ammonia: A review of measurements and a development of a big-leaf model for applications in regional-scale air-quality models, J. Geophys. Res.-Atmos., 115, D20310, doi:10.1029/2009JD013589, 2010.

Zhu, L., Henze, D. K., Cady Pereira, K. E., Shephard, M. W., Luo, M., Pinder, R. W., Bash, J. O., and Jeong, G. R.: Constraining US ammonia emissions using TES remote sensing observations and the GEOS-Chem adjoint model, J. Geophys. Res.-Atmos., 118, 3355-3368, doi:10.1002/jgrd.50166, 2013. 